\title{
P2Y blockade might help control bladder storage symptoms
}

Selective $\mathrm{P}_{2} \mathrm{Y}_{6}$ receptor blockade shows promise for controlling persistent storage symptoms in men with bladder outlet obstruction associated with benign prostatic hyperplasia (BPH), according to a new study.

Isabel Silva et al. investigated the role of the $\mathrm{P} 2 \mathrm{Y}_{6}$ receptor on the release of nonneuronal ATP and $\left[{ }^{3} \mathrm{H}\right]$ acetylcholine (ACh) from human urothelium strips (including lamina propria) collected from patients with $\mathrm{BPH}$ and from control organ donors.

The researchers found that the ATP/ $\left[{ }^{3} \mathrm{H}\right] \mathrm{ACh}$ ratio was fivefold higher in urothelium strips from patients with $\mathrm{BPH}$ than in those from controls. They also found that the selective $\mathrm{P}_{2} \mathrm{Y}_{6}$ receptor agonist increased ATP and $\left[{ }^{3} \mathrm{H}\right] \mathrm{ACh}$ release from the urothelium strips to a similar degree in both groups. This effect was blocked by a $\mathrm{P} 2 \mathrm{Y}_{6}$ receptor blocker.

Using immunofluorescence confocal microscopy data, the researchers showed that the $\mathrm{P} 2 \mathrm{Y}_{6}$ receptor is widely expressed in the human urothelium. The authors say that activation of the $\mathrm{P}_{2} \mathrm{Y}_{6}$ receptor facilitates the release of ATP and ACh from urothelial sources, thereby contributing to the initiation and local propagation of signals from the human urothelium to underlying bladder layers.

"Activation of the $\mathrm{P} 2 \mathrm{Y}_{6}$ receptor amplifies mucosal ATP release underlying bladder overactivity in BPH patients," explain the authors. "Therefore, we propose the use of selective $\mathrm{P} 2 \mathrm{Y}_{6}$ receptor blockade as a novel therapeutic strategy to control persistent storage problems in obstructed patients."

\section{Rebecca Kelsey}

Original article Silva, I. et al. Activation of $\mathrm{P} 2 \mathrm{Y}_{6}$ receptors facilitates non-neuronal ATP and acetylcholine release from urothelium with the lamina propria of men with bladder outlet obstruction. J. Urol. doi:10.1016/ j.juro.2015.05.080 